\title{
Analysis of the Effect of Current Ratio, Cooperative Size, Debt to Equity Ratio and Number of Members on Return On Assets at Primkop Kartika Puskop Line Kartika Bhirawa Anoraga, Indonesia
}

\author{
Kukuh Winasis ${ }^{1}$, Grahita Chandrarin ${ }^{2}$ and Harmono ${ }^{2}$ \\ Magister Management Program at University of Merdeka Malang, Indonesia \\ Faculty of Economics and Business, University of Merdeka Malang \\ Indonesia
}

\begin{abstract}
This study aims: 1) to determine the factors that influence the Remaining Operating Results (SHU) on Primkop Kartika KBA Puskop Line, 2) to Analyze the Effect of Current Ratio, Cooperative Size, Debt To Equity Ratio And Number of Members Against Return On Assets in Primkop Kartika KBA Puskop Line ranks 3) to test and analyze variables that have a significant influence between Current Ratio, Cooperative Size, Debt To Equity Ratio and Number of Members in Primkop Kartika KBA Puskop Line ranks. The data taken in this study are data from Primkop Kartika financial reports in the KBA Puskop Board of 2015-2018 period. The method used is the time series method. For the formulation of the problem, objectives and research hypotheses, the analysis used is the model specification test, multiple linear regression analysis, $t$ test, and $F$ test. The results showed that 1$)$ the factors that influence Return on Assets in Primkop Kartika KBA Puskop Board of Staff are Cooperative Size and Number of Members, 2) Current Ratio, Cooperative Size, Debt To Equity Ratio And Number of Members influential together to increase SHU Primkop Kartika KBA Puskop Line ranks, and 3) among Current Ratio, Cooperative Size, Debt To Equity Ratio and Number of Members that have a significant influence on increasing SHU Primkop Kartika KBA Puskop Line ranks are Cooperative Size and Number of Members.
\end{abstract}

Keywords: Current Ratio, Cooperative Size, Debt To Equity Ratio, Number of Members.

\section{INTRODUCTION}

Law No. 25 of 1992 also mandates that cooperatives are a family-based business entity that aims to improve the welfare of its members as stated in Cooperatives. Cooperatives which are seen as the cornerstone of the economy are expected to remain able to survive amid the changing times of the age of business competition. The development and empowerment of cooperatives in a cooperative policy must reflect the values and principles of cooperatives as a vehicle for joint efforts to meet the aspirations and economic needs of members so that they grow strong, healthy, independent and resilient in the face of increasingly dynamic and challenging national and global economic developments. Cooperatives are required to be able to continue to run their businesses by continuously improving performance in organizing them in order to achieve the expected goals. To measure performance results a performance measurement is needed. Performance measurement is important to assess the performance that has been carried out by the organization and can evaluate the activities that have been carried out.

In line with the aforementioned objectives, the government through the TNI AD institution forms a business entity in the form of a functional cooperative namely the TNI AD Cooperative with a tiered structure: Main Kartika Cooperative at the central level, Kartika Cooperative Center at the Kotama level and Primary Cooperatives at the unit level, having a Vision: Realizing Cooperatives as National Economic Power and Mission: Prospering Soldiers and Civil Servants of the Indonesian Army and their families.

Based on Law No. 17 of 2012 CHAPTER XIV Empowerment, Role of the Government and in Perkadad No. 14 / V / 2010 dated 18 May 2010 concerning Cooperative Organizations within the Army, regarding the role of the Army in economic activities, including: Structural Monitoring, Monitoring and Evaluation from the level of the lower level cooperative organizations to the central level, so that it can be achieved goals in accordance with the vision and mission of the Army Cooperative

At Kodam V / Brawijaya for the unit level, the Primary Cooperative monitoring, monitoring and evaluation functions are carried out by Puskop Kartika Bhirawa Anoraga assisted by the local Cooperative Office as part of encouraging unit-level cooperatives (primary cooperatives) to grow and develop properly. Where both Puskop Kartika Bhirawa Anoraga as the 
supervisor and the Department of Cooperatives requires the Primary Cooperative to always present financial reports and accountability reports of cooperative management both month, quarter, semester and close the book.

Judging from the report on the Remaining Business Results (SHU) obtained by Primary Cooperative Cooperative in the KBA Puskop Line for four years there was a fluctuation as shown in table 1.

Table 1 Development of the Remaining Operations (SHU) of Primary Cooperatives at the KBA Puskop Line 2015 -2018

\begin{tabular}{|c|c|}
\hline Year & SHU \\
\hline 2015 & $42,751,535,480$ \\
2016 & $44,542,534,150$ \\
2017 & $53,736,385,424$ \\
2018 & $61,751,715,281$ \\
\hline
\end{tabular}

Source: Kartika Bhirawa Anoraga Cooperative Center

Based on the data above, the profit ratio between 2015-2016 experienced an increase of 4.02\% and 2016-2017, an increase of $20.64 \%$ and $2017-2018$ an increase of $14.92 \%$.

SHUnecessary to assess changes in potential economic resources that may be able to be controlled in the future that are able to generate cash flow and existing resources and formulation of considerations for the effectiveness of cooperatives in utilizing resources and for members as owners of capital. The method that can be used by cooperatives to evaluate and perfect their performance is to analyze the cooperative's financial performance. This analysis also looks at the successes and weaknesses of cooperatives by using cooperative financial ratios. This analysis shows the ability of cooperatives in 3 (three) things that are indicators of business achievement, namely profitability, liquidity and leverage as well as efficiency. This analysis also looks at the successes and weaknesses of cooperatives by using financial ratios.

With this analysis, the Primary Cooperative of the Kartika Bhirawa Anoraga Line of Cooperatives can be seen the health level of each cooperative so that a decision can be made on the cooperative.

Based on the description, the authors are interested in researching on "Analysis of the Effect of Current Ratio, Cooperative Size, Debt To Equity Ratio And The Number Of Members Of Return On Assets In Primkop Kartika Kartika Bhirawa Anoraga Puskop Lineage"

\section{THEORETICAL BASIS}

\subsection{Return on assets}

Return on assetsis one of the profitability ratios used to measure the effectiveness of a company in generating profits by utilizing the total that it has. Or compare the results of operations obtained with cooperative assets in the year concerned. In a cooperative ROA is a comparison between the results of operations obtained with cooperative assets in the year concerned. The greater ROA shows the better company performance, because the greater the return. ROA calculation consists of:

1) Calculate Earning Before Tax company profit (cooperative) before tax deduction.

2) Calculate the total assets owned by the cooperative consisting of current assets and fixed assets.

The purpose of using Return On Assets is as a criterion for evaluating results of operations with the main objectives that can be used as:

a. An indicator of management effectiveness

As an indicator of the effectiveness of management is able to describe the ability of companies to earn profits by comparing the capital they have to generate profits, so it can be said that profitability is a manifestation of management effectiveness and quality.

b. A tool for making corporate profit projections

As a tool to make a projection of corporate profits because profitability is able to describe the correlation or relationship between earnings and capital used to produce these profits. Therefore, managers can analyze and plan profits at various levels of change that are planted.

c. A controlling tool for management

As a controlling tool for management because profitability can also be used as a control tool in setting targets (plans), budgets, coordination, evaluating the results of the company's operations and alternative evaluation criteria as well as the basis for investment decision making.

\subsection{Current Ratio}

Understanding the current ratio according to Kasmir states that the current ratio is a ratio to measure the ability of companies to pay short-term liabilities or debt that are due immediately when billed as a whole. In other words, how much current assets are available to cover short-term liabilities that are immediately due [1]. The current ratio can also be said as a form of 
measuring the level of safety (margin of safety) of a company. According to Fahmi "current ratio is a measure commonly used for short-term solvency, the ability of a company to meet debt needs when due" [2].

Meanwhile according to Atmaja: Current ratio is the financial ratio used to determine the liquidity of a company [3]. This ratio is calculated by dividing current assets with current debt. Low current ratio shows that the company's liquidity is bad. Conversely, if the current ratio is relatively high, the company's liquidity is relatively good. However, it must be noted that not in all cases where the current ratio is high, the company's liquidity must be good. Although current assets are greater than current liabilities, it is important to remember that current assets items such as inventories and receivables are sometimes difficult to collect or sell appropriately. According to Hanafi and Halim states that: the current ratio is calculated by dividing current assets with current debt [4]. This ratio shows the amount of cash owned by the company plus assets that can turn into cash within one year, relative to the amount of debts that are due in the near term (no more than 1 year), at a certain date as stated on the balance sheet. According to S. Munawir states that: The most common ratio used to analyze the working capital position of a company is the Current Ratio, the ratio between the amount of current assets and current debt [5]. This ratio shows that the value of current assets (which can immediately be used as money) is the number of short-term debt. According to S. Munawir (2007: 72) states that: The most common ratio used to analyze the working capital position of a company is the Current Ratio, the ratio between the amount of current assets and current debt. This ratio shows that the value of current assets (which can immediately be used as money) is the number of short-term debt. According to S. Munawir states that: The most common ratio used to analyze the working capital position of a company is the Current Ratio, the ratio between the amount of current assets and current debt. This ratio shows that the value of current assets (which can immediately be used as money) is the number of short-term debt [5].

\subsection{Cooperative Size}

According to Machfoedz in Suwito and Herawati, company size is a scale in which large companies can be classified according to various ways, including: total assets, log size, stock market value, and others [6]. Basically, the size of the company is only divided into 3 categories, namely large companies, medium-size companies and small firms. Determination of the size of the company is based on the company's total assets.

According to the set of laws and regulations in the field of cooperative institutions in Palupi, the size of cooperatives can be seen based on annual turnover (business volume) contained in the business development report [7]. Based on the turnover, the size of cooperatives is classified into three groups, namely large cooperatives, medium cooperatives, and small cooperatives.

1) Large cooperatives have a turnover (business volume) above Rp 1 billion in 1 (one) year.

2) Medium cooperatives have a turnover (business volume) of between Rp 500 million to Rp 1 billion in 1 (one) year.

3) Small cooperatives have a turnover (business volume) of less than Rp 500 million in 1 (one) year.

\subsection{Debt To Equity Ratio}

Understanding Debt to Equity Ratio according to Darsono and Ashari, namely Debt to Equity Ratio is one of the leverage or solvency ratios. Solvency ratio is the ratio to find out the company's ability to pay liabilities if the company is liquidated [8]. This ratio is also called the leverage ratio (Leverage), which assesses the company's limits in borrowing money. Horne and Machowicz which were translated by James suggested that "leverage is the use of fixed costs in an effort to increase (level up) profitability" [9]. While the definition of Debt to equity ratio according to Gibson is "Debt equity ratio is another computation thats determines the entity's long-term debt-paying ability" [10]. That is, the debt to equity ratio is another computation that determines the ability to pay long-term debt of an entity. According to Sugiyono, states that: This ratio shows the ratio of debt and capital. This ratio is one of the important ratios because it is related to the problem of trading on equity, which can have a positive and negative influence on the profitability of equity capital and the company [11].

Meanwhile according to Kasmir, states that: Debt to equity ratio is the ratio used to assess debt with equity [1]. This ratio is sought by comparing all debt, including current debt and all equity. This ratio is used to determine the amount of funds provided by the borrower (creditor) with the owner of the company.

\subsection{Number of Cooperative Members}

According to Baswir cooperative members are individuals who are part of the cooperative in accordance with predetermined requirements [12]. As a cooperative member must pay a sum of money for the principal savings and cooperative compulsory savings. Every Indonesian citizen basically has the right to become a member of a cooperative, but because a cooperative is a legal entity that will take legal actions, the only truly acceptable members of a cooperative are those who are able to take legal action or cooperative action, and who meet the requirements in accordance with the cooperative's articles of association and by-laws.

The large number of cooperative members will be useful as additional capital obtained from the principal savings and mandatory savings. Status of cooperative members in cooperative business entities are as owners and as users. As owner, 
members must be able to participate in annual member meetings (RATs) and participate in raising capital for cooperative business activities. As users, cooperative members must truly utilize the business activities carried out by cooperatives. The more economic relationships between members and cooperatives, the greater the possibility of the development of cooperatives (Sitio and Tamba) [13].

\section{RESEARCH METHODOLOGY}

This study discusses the influence of Current Ratio, Cooperative Size, Debt To Equity Ratio and Number of Members Against Return On Assets in Primkop Kartika Kartika Bhirawa Anoraga Puskop Line. The variables in this study are Current Ratio $\left(\mathrm{X}_{1}\right)$, Cooperative Size $\left(\mathrm{X}_{2}\right)$, Debt To Equity Ratio $\left(\mathrm{X}_{3}\right)$, and Number of Members $\left(\mathrm{X}_{4}\right)$ as independent variables that will affect the dependent variable, namely Return On Assets (Y). $\mathrm{X}_{1} \mathrm{X}_{2} \mathrm{X}_{3} \mathrm{X}_{4}$

Research Design or research design is a framework or plan for conducting studies that will be used as a guide in collecting and analyzing data. Kerlinger, argues that the research design is the whole process needed in the planning and implementation of research. The research design is defined as a strategy to set the research background so that researchers obtain valid data in accordance with the characteristics of the variables and research objectives. In other words, the research design is a research plan and structure that are arranged so that the researcher can get answers to his research questions. This research is explanatory research that is research that aims to analyze the influence of variables, by looking at the level of significance. Then this study explains the phenomenon between the two variables to test the hypothesis whether there are an influence and significant level of independent variables namely Current Ratio, Cooperative Size, Debt to Equity Ratio and the Number of Members of the dependent variable namely Return On Asset Primary Cooperative Cooperative Line of Kartika Bhirawa Anoraga.

Research hypotheses are developed based on theories that are then tested based on data collected and processed using a regression model.

To clarify the research design can be seen in Figure 1.

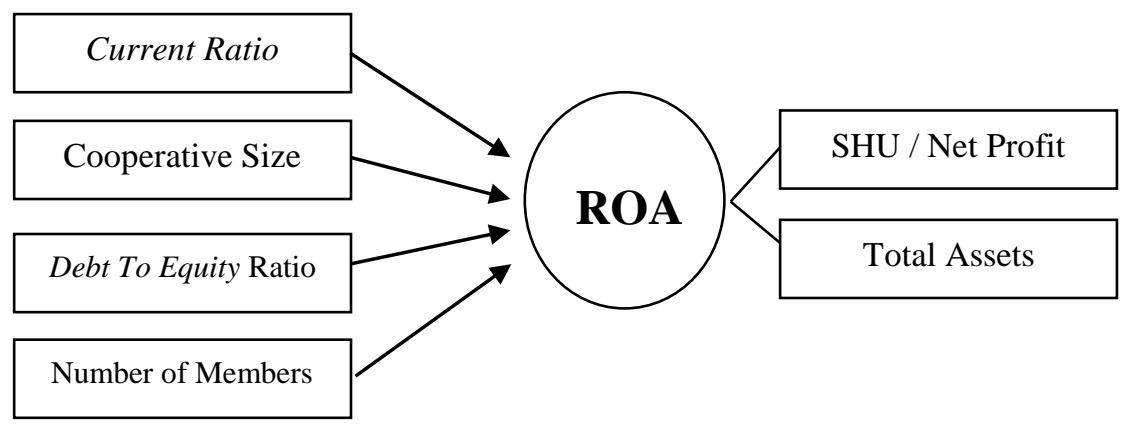

Figure1 Research Conceptual Framework

\section{RESEARCH RESULTS AND DISCUSSION}

\subsection{Descriptive Statistics Test}

From the results of the table 2 it can be seen that the amount of data used in the study was 81 data taken from 30 cooperatives with a 4-year research data period, namely the period $2015-2018$.

Table 2. Descriptive Statistics Test Results

\begin{tabular}{|c|r|r|r|r|}
\hline Variable & \multicolumn{1}{|c|}{ Min } & \multicolumn{1}{c|}{ Max } & \multicolumn{1}{c|}{ The mean } & \multicolumn{1}{c|}{ Std Deviation } \\
\hline ROA & 2.85 & 17.36 & 8.9547 & 3,06487 \\
CR & 192.51 & 3624.99 & 799,7742 & 736,26813 \\
SIZE & 20.24 & 23.68 & 22,2574 & .69176 \\
DER & 1.29 & 140.89 & 42,8685 & 35.85397 \\
MEMBER & 87.00 & 859.00 & 342,4000 & 184,11329 \\
\hline
\end{tabular}

Source: Secondary data processed in 2020 (SPSS output)

Return on assets the data above has a minimum value of 2.85, a maximum value of 17.36 and an average value of $8.9547 \%$, to see how much the deviation of data on Return On Assets seen from the standard deviation that is equal to 3.06487\%, meaning that the mean value is greater than the standard value so that the data deviation that occurs is low then the spread of the value is evenly distributed. 
Current Ratio have the minimum value is 192.51, the maximum value is 3624.99 and an average value of $799.7742 \%$ statistically it is said that as Return On Assets increases, the Current Ratio will increase, to see how much the deviation of data in the Current Ratio ratio can be seen from the standard deviation of $736.26813 \%$.

Cooperative Size Data (Size) in the data above hasa minimum value of 20.24, a maximum value of 23.68 and an average value of $22.2574 \%$, to see how much the deviation of data in Size seen from the standard deviation that is equal to $0.69176 \%$. In this case the Primkop Kartika Size KBA Puskop Line can be said to be good, because the standard deviation is smaller than the mean value.

Debt to Equity Ratio data has a minimum value of 1.29, a maximum value of 140.89 and the average value of Debt to Equity Ratio of $42.8685 \%$ statistically increased Return On Assets, the Debt Equity Ratio will decrease, to see how much the data deviation in the Debt to Equity Ratio ratio can be seen from the standard deviation that is equal to $35.85397 \%$. In this case, the Debt to Equity Ratio variable data in Primkop Kartika Kartkop Kartika ranks can be said to be good, because the standard deviation value is smaller than the mean value.

Data on the number of members hasa minimum value of 87.00 , a maximum value of 859.00 and an average value of $342.4000 \%$ statistically where an increasing number of members then Return on assets increasing, to see how much the deviation of data in this ratio can be seen from the standard deviation that is equal to $184.11329 \%$.

\subsection{Model Accuracy Test (F Test) and Determination Coefficient Test $^{2}$ ) Simultaneous Test (F Test)}

The statistical test $\mathrm{F}$ aims to show whether all independent variables included in the research model have a joint influence on the Return On Asset variable in the Primary Cooperative Cooperative in the KBA Puskop.

Table 3 Test Results F

\begin{tabular}{|l|c|c|c|c|c|c|}
\hline \multicolumn{2}{|c|}{ Model } & $\begin{array}{c}\text { Sum of } \\
\text { Squares }\end{array}$ & df & $\begin{array}{c}\text { Mean } \\
\text { Square }\end{array}$ & F & Sig \\
\hline \multirow{3}{*}{1} & Regression & 531,269 & 4 & 132,817 & 26,041 & 0,000 \\
\cline { 2 - 7 } & Residual & 586,547 & 115 & 5,100 & & \\
\cline { 2 - 7 } & Total & 1117,816 & 119 & 132,817 & & \\
\hline
\end{tabular}

Source: Secondary data processed by 2020 (SPSS Output)

From the F test results obtained by the number $\mathrm{F}$ of 26,041 and the significance value is 0,00 , the probability is much smaller than 0.05 or $5 \%$, then the regression model can be used precisely to predict Return On Assets in other words that Current Ratio, Size, Debt to Equity Ratio, and Number of Members simultaneously and significantly affect variables Return on assets.

\section{Coefficient of Determination $\left(\mathbf{R}^{2}\right)$}

The coefficient of determination $\left(\mathrm{R}^{2}\right)$ of the regression model is used to find out how much Return On Assets in the Primary Cooperative Cooperative Line KBA can be explained by the independent variables. The results of the calculation of the coefficient of determination can be seen in the following table:

Table 4 Determination of $\mathbf{R}$ Square $\left(\mathbf{R}^{2}\right)$

\begin{tabular}{|c|c|c|c|r|}
\hline Model & R & R Square & $\begin{array}{c}\text { Adjusted R } \\
\text { Square }\end{array}$ & $\begin{array}{c}\text { Standard Error } \\
\text { of the Estimate }\end{array}$ \\
\hline 1 & .689 & 0.475 & \multicolumn{2}{|c|}{.457} \\
\hline \multicolumn{3}{r}{ Sumber: Secondary Data processed 2020 (SPSS Output) }
\end{tabular}

Based on table 4 the magnitude of $R$ square $\left(R^{2}\right)$ is 0.475 . This means that $47.5 \%$ of the independent variables namely Current Ratio, Size, Debt to Equity Ratio, and Number of Members affect the dependent variable, namely Return On Assets, while the remaining $52.5 \%$ is influenced by other factors not included in the model regression transformation.

\section{Variable Significance Test (t test)}

Partial test ( $\mathrm{t}$ test) is used to determine the effect of each independent variable on Return On Assets. Based on the partial results of SPSS, the results of the regrets are shown in Table 9 below: 
International Journal of Advances in Scientific Research and Engineering (ijasre), Vol 6 (8), August -2020

Table 5 T Test Results

\begin{tabular}{|c|c|c|c|c|c|c|}
\hline \multicolumn{2}{|c|}{ Variable } & \multicolumn{2}{c|}{$\begin{array}{c}\text { Unstandardized } \\
\text { Coefficients }\end{array}$} & $\begin{array}{c}\text { Standardized } \\
\text { Coefficients }\end{array}$ & t & Sig. \\
\hline \multirow{4}{*}{1} & B & Std. Error & Beta & & \\
\cline { 2 - 7 } & (Constant) & $-66,546$ & 9,360 & & $-7,110$ & 0,000 \\
\cline { 2 - 7 } & CR & 0,000 & 0,000 & $-0,062$ & $-0,851$ & .397 \\
\cline { 2 - 8 } & SIZE & 3,657 & 0.438 & 0.825 & 8,341 & $0,000 *$ \\
\cline { 2 - 8 } & DER & -011 & 0.006 & $-0,135$ & $-1,961$ & 0.052 \\
\cline { 2 - 8 } & ANGG &,- 015 & 0.002 & $-0,910$ & $-8,809$ & $0,000 *$ \\
\hline
\end{tabular}

Source: Secondary data processed by 2020 (SPSS Output)

Based on the table, the influence of Current Ratio, Size, Debt to Equity Ratio, and Number of Members can be stated as follows:

1) Current Ratio

Regression coefficient of 0.00 and $t$ value of -0.851 and sig. $=0.397$ is greater than 0.05 . These results indicate that the Current Ratio has a negative effect on Return On Assets in Primkop KBA Puskop Line. This means that if the Current Ratio experiences an increase / decrease does not affect the Return On Asset or it can also be said to have not increased or decreased.

2) Cooperative Size (Size)

Regression coefficient of -0.011 and $t$ value of 8.341 and sig. $=0.00$ smaller than 0.05 , means that the Size variable has a positive effect on the level of Return On Assets in the Primkop KBA Puskop Line. If Size increases by 1\%, the level of Return On Assets will increase by $3.657 \%$ with the other variable conditions constant.

3) Debt to Equity Ratio (DER)

Regression coefficient of 3.657 and $t$ value of -1.961 and sig. $=0.052$ is greater than 0.05, means that the variable Debt to Equity Ratio has a negative effect on Return On Assets. If Debt to Equity Ratio has decreased by 1\%, then this Return On Assets has increased by $0.011 \%$.

4) Number of Members

Regression coefficient of $-0,015$ and $t$ value of $-8,809$ and sig. $=0,000$ less than 0.05 that the variable Number of Members has a positive effect on Return On Assets. If the number of members rises by $1 \%$ then this causes the Return On Asset level to rise by $0.015 \%$.

Based on the results of table 9 of the t-test results of the regression model, the first hypothesis testing (H1), second hypothesis (H2), third hypothesis (H3), fourth hypothesis (H4), and by obtaining:

1) Testing the first Hypothesis (H1)

$\mathrm{H} 1=$ Current Ratio affects the Return On Assets (ROA)

Based on the results of the $t$-test where the sign value is greater than the probability value of 0.397 or $0.397>0.05$ then $\mathrm{H} 0$ is accepted and H1 is rejected, meaning that the Current Ratio has no effect on Return On Assets, it can be said that the research hypothesis stating Current Ratio has an effect on Return On Assets rejected.

2) Second Hypothesis Testing (H2)

$\mathrm{H} 2$ = Size (Size) affects the Return On Asset (ROA).

Based on the results of calculations with the regression model, the sign value is smaller than the probability value of 0.05 , or $0,000<0.05$, so where $\mathrm{H} 0$ is rejected and H2 is accepted, meaning that Size influences Return On Assets, that the research hypothesis stating Cooperative Size ( Size) affect the Return On Asset received.

3) Third Hypothesis Testing (H3)

H3 = Debt to Equity Ratio affects Return on Assets (ROA).

Based on the results of the t-test regression model obtained where the sign value is greater than the probability value of 0.05 , or 0.052> 0.05, then $\mathrm{H} 0$ is accepted and $\mathrm{H}$ (3) is rejected, meaning that Debt to Equity Ratio has no effect on Return on Assets, the hypothesis in the study which states Debt to Equity Ratio has an effect on Return On Assets is rejected.

4) Fourth Hypothesis Testing (H4)

$\mathrm{H} 4=$ Number of Members influences Return on Assets (ROA).

Based on the results of the $t$-test regression model, the sign value is greater than the probability value of 0.05 , or $0,000<0.05$, then $\mathrm{H} 0$ is rejected and $\mathrm{H} 4$ is accepted, meaning that the hypothesis stating the number of members has no effect on Return On Assets is rejected. The research hypothesis states that the number of members influences the return on assets received. 


\section{CONCLUSION}

Based on the analysis of the effect of Current Ratio, Size, Debt Equity Ratio, and Number of Members on Return On Assets, then concluded as follows:

1) Current ratio no effect on Return On Assets in cooperatives in Primkop KBA Puskop Line

2) Cooperative Size (Size) positive effect on Return On Assets in Primkop KBA Puskop Line

3) Debt Equity Ratio no effect on Return On Assets in Primkop KBA Puskop Line

4) Number of members influential positive for Return On Assets in Primkop KBA Puskop Line

Based on the conclusions, the authors suggest the following:

1) Cooperatives in the KBA Puskop Line in decision making to improve Return on assets need to increase the ratio of Current Ratio, Size, Debt to Equity Ratio, and Number of Members

2) Cooperatives in the KBA ranks of Puskop in making decisions on Return on assets can simultaneously use the variable Current Ratio, Size, Debt Equity Ratio, and Number of Members

3) Cooperatives in the KBA ranks of Puskop in making decisions on Return on assetscan partially use the Size and Number of Members as an effort to increase member participation. without ignoring the variable Current Ratio and Debt To Equity Ratio.

4) In future research it is necessary to use other variables that can influence Return on assets that have not been studied in this study such as Working Cash Turn Over, Debt to Asset Ratio, Working Capital Turn Over.

5) Future research needs field research to increase the amount of data and the time period of the study and the sample of cooperatives.

\section{REFERENCES}

1. Kasmir. 2014. Pengantar Manajemen Keuangan. Jakarta : PT. Raja Grafindo Persada

2. Fahmi, Irham. 2012. Analisis Kinerja Keuangan. Penerbit CV Alfabeta, Bandung

3. Atmaja, Lukas Setia. 2008. Teori dan Praktek Manajemen Keuangan. Yogyakarta: Penerbit ANDI.

4. Halim, Abdul dan Mamduh M. Hanafi. 2009. Analisis Laporan Keuangan. Edisi. 4. UPP STIM YKPN. Yogyakarta

5. Munawir. 2014. Analisa Laporan Keuangan. Yogyakarta: Liberty.

6. Suwito, Edy dan Arleen Herawaty. 2005. Analisis Pengaruh Karakteristik Perusahaan terhadap Tindakan Perataan Laba yang dilakukan oleh Perusahaan yang Terdaftar di Bursa Efek Jakarta. Simposium Nasional Akuntansi VIII. Solo. 15-16 September.

7. Palupi, Indria. 2011. Pengaruh Profitabilitas, Ukuran Perusahaan, Likuiditas, Struktur Aktiva dan Tingkat Pertumbuhan Perusahaan terhadap Struktur Modal Studi Empiris pada Perusahaan Manufaktur yang Terdaftar di Bursa Efek Indonesia Tahun 2007-2009. Tesis. Universitas Sebelas Maret: Solo.

8. Darsono \& Ashari, 2010. Pedoman Praktis Memahami Laporan Keuangan. Penerbit Andi. Yogyakarta.

9. Hall, James A. 2009. Sistem Informasi Akuntansi. (Terjemahan Dewi Fitriasari dan Deny Arnos Kwary). Edisi 4. Jakarta: Salemba Empat.

10. Gibson, M. 2008. Manajemen Sumber Daya Manusia. Cetakan ke dua. Jakarta: Erlangga.

11. Sugiyono. 2009. Metode Penelitian Kuantitatif, Kualitatif dan R\&D, Bandung.

12. Baswir, Revrisond. 2012. Koperasi Indonesia, Jakarta: Salemba Empat

13. Sitio, Atifin dan Tamba Halomoan. 2001. Koperasi : Teori dan Praktik. Jakarta : Erlangga. 